\title{
PERILAKU MEROKOK PADA PENDERITA HIPERTENSI DI DESA SIDOKARTO KECAMATAN GODEAN, SLEMAN, YOGYAKARTA
}

\author{
Septian Emma Dwi Jatmika, Muchsin Maulana \\ Fakultas Kesehatan Masyarakat, Universitas Ahmad Dahlan, Yogyakarta \\ Email: iandjee@rocketmail.com
}

\begin{abstract}
Background: Hypertension is almost always associated with a change in lifestyle, one of which is smoking. One way to prevent hypertension is by controlling risk factors. It can also reduce the risk of hypertension patients to undergo further complications.

Methods: The study was descriptive with a sample of 30 people who met the inclusion criteria. This study used questionnaire containing a series of questions about knowledge, attitudes and behaviors associated with hypertension and smoking behavior.

Results: The results showed that the most of (66.67\%) respondents smoking behavior were less good and a fraction (33.33\%) were moderate behavior. Knowledge about smoking behavior of respondent majority (46.67\%) were moderate and a fraction (10\%) were less good. While the respondents' attitudes toward smoking behavior majority (63.33\%) were negative.

Conclusion: Overview of knowledge, attitudes and smoking behavior in patients with hypertension, especially the smoke in the village of Godean Sidokerto District of Sleman Yogyakarta remains largely low.
\end{abstract}

Keywords: knowledge, attitudes, smoking behavior, patients with hypertension

\begin{abstract}
Abstrak
Latar Belakang: Penyakit hipertensi hampir selalu dikaitkan dengan perubahan gaya hidup atau pola hidup, salah satunya adalah merokok. Pencegahan terjadinya hipertensi salah satunya dengan mengendalikan faktor resiko. Hal ini juga dapat mengurangi resiko penderita untuk mengalami hipertensi lanjut dengan komplikasi.

Metode: Jenis penelitian yang digunakan adalah deskriptif dengan jumlah sampel sebesar 30 orang yang memenuhi kriteria inklusi. Pada penelitian ini menggunakan instrumen penelitian berupa kuesioner yang berisi serangkaian pertanyaan tentang pengetahuan, sikap dan perilaku yang berhubungan dengan kejadian hipertensi dan perilaku merokok.

Hasil: Hasil penelitian menunjukkan bahwa sebagian besar $(66,67 \%)$ perilaku merokok responden adalah kurang baik dan sebagian kecil (33,33\%) perilaku responden adalah cukup baik. Pengetahuan responden tentang perilaku merokok sebagian besar $(46,67 \%)$ adalah cukup baik dan sebagian kecil (10\%) adalah kurang baik. Sedangkan sikap responden terhadap perilaku merokok sebagian besar $(63,33 \%)$ adalah negatif.

Kesimpulan: Gambaran pengetahuan, sikap dan perilaku merokok pada penderita hipertensi khususnya yang merokok di Desa Sidokerto Kecamatan Godean Kabupaten Sleman Yogyakarta sebagian besar masih kurang baik.
\end{abstract}

Kata kunci: pengetahuan, sikap, perilaku merokok, penderita hipertensi

\section{Pendahuluan}

Merokok sudah menjadi lifestyle pada kebanyakan penduduk di negara bekembang, termasuk Indonesia. Perilaku merokok di Indonesia pada penduduk 15 tahun keatas masih belum terjadi penurunan dari 2007 ke 2013, bahkan cenderung meningkat dari 34,2\% tahun 2007 menjadi 36,3\% tahun 2013. Dijumpai 64,9\% laki-laki 
dan $2,1 \%$ perempuan masih menghisap rokok pada tahun 2013. Sedangkan rerata jumlah batang rokok terbanyak yang dihisap perhari ditemukan di Bangka Belitung (18,3 batang). ${ }^{1}$

Merokok telah terbukti berdampak buruk bagi kesehatan. Hasil penelitian mengungkapkan bahwa merokok terbukti menyebabkan peningkatan denyut jantung, tekanan darah dan kadar katekolamin yang berperan penting sebagai penyebab kelainan jantung. Selain itu, kebiasaan merokok pada penderita hipertensi meningkatkan risiko kardiovaskuler lainnya seperti terjadinya penyakit jantung koroner (PJK), stroke, gagal jantung, dan penyakit arteri perifer. ${ }^{2}$ Hasil penelitian lain menyatakan bahwa hipertensi ditambah kebiasaan merokok dapat menimbulkan atherosklerosis dini. Oleh karena itu dapat disimpulkan bahwa merokok adalah salah satu faktor dari hipertensi dan dapat menyebabkan komplikasi penyakit lain. ${ }^{3}$

Hipertensi mendapat julukan "The Silent Killer" karena penyakit ini sering membuat penderitanya "kecolongan". Prevalensi hipertensi berdasarkan pengukuran tekanan darah menunjukkan penurunan dari 31,7\% tahun 2007 menjadi 25,8\% tahun 2013. Asumsi terjadi penurunan bisa bermacam-macam mulai dari alat pengukur tensi yang berbeda sampai pada kemungkinan masyarakat sudah mulai datang berobat ke fasilitas kesehatan. Namun prevalensi hipertensi berdasarkan wawancara (apakah pernah didiagnosis nakes dan minum obat hipertensi) terjadi peningkatan dari $7,6 \%$ tahun 2007 menjadi 9,5\% tahun 2013. ${ }^{1}$ Sedangkan prevalensi hipertensi di Daerah Istimewa Yogyakarta masuk dalam lima besar provinsi dengan kasus hipertensi terbanyak yaitu sebesar $35,8 \%{ }^{4}$

Jumlah kasus hipertensi tersebut tidak lepas dari faktor risiko, bahwa faktor risiko seseorang untuk menderita hipertensi ditentukan melalui interaksi dua atau lebih faktor risiko antara lain: faktor yang tidak dapat dikendalikan (non modifiable risk factors) dan faktor yang dapat dikendalikan (modifiable risk factors). Faktor yang tidak dapat dikendalikan terdiri dari umur dan jenis kelamin. Faktor yang dapat dikendalikan terdiri dari merokok, hipertensi, penyakit diabetes mellitus, obesitas dan dislipidemia. ${ }^{5}$

Penyakit hipertensi hampir selalu dikaitkan dengan perubahan gaya hidup atau pola hidup. Mengingat hipertensi dapat mengalami komplikasi dari yang ringan sampai yang berat seperti stroke maka diperlukan suatu usaha untuk menurunkan tingkat prevalensi hipertensi dimasyarakat. Penurunan ini dapat dilakukan melalui pengobatan penyakit hipertensi yang sudah ada. Namun melihat kondisi penyakit hipertensi yang terkadang tidak disadari penderita maka usaha case finding perlu dilakukan. Hal lain yang dapat dilakukan adalah dengan mencegah timbulnya penyakit hipertensi, salah satunya dengan mengendalikan faktor risiko. Mengendalikan faktor-faktor ini dapat mengurangi risiko penderita untuk mengalami hipertensi lanjut dengan komplikasi.

Hasil pencapaian tahun 2011, yang memberikan kontribusi terendah dan masih menjadi masalah kesehatan pada umumnya adalah tidak merokok di dalam rumah yang baru mencapai 46,67\%. Hasil Riskesdas 2010 menunjukkan bahwa prevalensi perokok di DIY sebesar 31,6\%, dan sebanyak 66,1\% masih merokok di dalam rumah. Persentase rumah tangga bebas asap rokok di DIY tahun 2012 baru mencapai 44,6\%. ${ }^{6}$

Desa Sidokarto merupakan daerah pedesan yang terletak di Kecamatan Godean, Kabupaten Sleman. Berdasarkan jumlah rokok yang dihisap perhari, prevalensi perokok pada penduduk yang tinggal di pedesaan lebih tinggi dibandingkan dengan yang tinggal di perkotaan. Prevalensi perokok yang menghisap 6-10 batang rokok/hari di pedesaan adalah sebesar $32,3 \%$ dan di perkotaan sebesar $27,4 \%{ }^{7}$ Untuk menurunkan angka hipertensi maupun kematian akibat hipertensi, maka pengetahuan dan perilaku merokok pada penderita hipertensi di Desa Sidokarto penting untuk diteliti sebagai dasar menetapkan intervensi untuk penderita hipertensi sehingga tidak menimbulkan komplikasi lain maupun kematian. 


\section{Metode Penelitian}

Jenis penelitian yang digunakan dalam penelitian ini adalah deskriptif yang bertujuan untuk mendeskripsikan atau mengambarkan pengetahuan dan sikap responden serta perilaku merokok responden. Penelitian dilakukan pada bulan Juni 2013 di Desa Sidokarto, Kecamatan Godean, Sleman, Yogyakarta. Sampel yang digunakan dalam penelitian ini sebanyak 30 orang responden yang diambil dengan teknik purposive sampling yaitu suatu teknik penetapan sampel dengan cara memilih sampel diantara populasi dengan kriteria inklusi yaitu pasien laki-laki yang terdiagnosis hipertensi, mempunyai kebiasaan merokok, pernah merokok, atau sudah berhenti merokok, tidak ada gangguan komunikasi serta bersedia menjadi responden. Instrumen penelitian menggunakan kuesioner yang berisi serangkaian pertanyaan tentang pengetahuan, sikap dan perilaku yang berhubungan dengan kejadian hipertensi dan merokok. Analisis data pada penelitian ini dilakukan dengan menggunakan proses komputerisasi dengan cara analisis univariat yaitu untuk memperoleh gambaran pada masing-masing variabel dengan menggunakan tabel distribusi frekuensi.

\section{Hasil Penelitian dan Pembahasan}

\section{A. Hasil Penelitian}

a. Karakteristik Responden Berdasarkan Umur

Tabel 1. Karakteristik responden di Desa Sidokarto Kecamatan godean berdasarkan umur

\begin{tabular}{ccc}
\hline Umur & Jumlah & $\%$ \\
\hline $40-50$ & 3 & 10 \\
$51-60$ & 8 & 26,67 \\
$61-70$ & 7 & 23,33 \\
$71-80$ & 11 & 36,67 \\
$81-90$ & 1 & 3,33 \\
Total & 30 & 100 \\
\hline
\end{tabular}

Berdasarkan Tabel 1 diatas, menunjukkan bahwa sebagian besar responden berumur $71-80$ tahun yaitu sebesar $36,67 \%$.

\section{b. Gambaran Determinan Perilaku Merokok Merokok Responden}

Tabel 2. Distribusi frekuensi perilaku merokok berdasarkan pengetahuan, sikap, dan perilaku merokok responden di Desa Sidokarto

\begin{tabular}{cccc}
\hline Variabel & Kategori & Jumlah & $\%$ \\
\hline \multirow{4}{*}{ Perilaku Merokok } & Baik & - & - \\
& Cukup baik & 10 & 33,33 \\
& Kurang baik & 20 & 66,67 \\
& Total & 30 & 100 \\
& Baik & 13 & 43,33 \\
& Cukup Baik & 14 & 46,67 \\
Pengetahuan & Kurang Baik & 3 & 10 \\
& Total & 30 & 100 \\
& Positif & 11 & 36,67 \\
& Negatif & 19 & 63,33 \\
& Total & 30 & 100 \\
\hline
\end{tabular}

Pada Tabel 2 sebagian besar responden memiliki perilaku merokok yang kurang baik yaitu sebesar $66,67 \%$. Pengetahuan responden tentang 
perilaku merokok sebagian besar cukup baik yaitu sebesar 46,67\%. Sedangkan sikap responden terhadap perilaku merokok sebagian besar memiliki sikap negatif yaitu sebesar $63,33 \%$.

Tabel 3. Distribusi frekuensi perilaku merokok pasien hipertensi di Desa Sidokarto

\begin{tabular}{|c|c|c|c|}
\hline & & & \\
\hline No & Variabel perilaku Merokok & Jumlah & $\%$ \\
\hline \multirow[t]{10}{*}{1.} & Merokok dalam 30 hari terakhir: & & \\
\hline & a. Merokok & & 33,33 \\
\hline & b. Tidak merokok & & 66,67 \\
\hline & Jumlah rokok yang dihisap selama 30 hari terakhir: & & \\
\hline & a. Tidak merokok dalam 30 hari & & 66,67 \\
\hline & b. 2-3 rokok / hari & & 10 \\
\hline & c. 4-6 rokok / hari & & 3,33 \\
\hline & d. 7-10 rokok / hari & & 3,33 \\
\hline & e. $11-20$ rokok / hari & & 3,33 \\
\hline & f. $>20$ rokok / hari & & 13,33 \\
\hline \multirow[t]{10}{*}{2.} & Merokok dalam 7 hari terakhir : & & \\
\hline & a. Merokok & 9 & 30 \\
\hline & b. Tidak merokok & 21 & 70 \\
\hline & Jumlah rokok yang dihisap selama 7 hari terakhir: & & \\
\hline & a. Tidak merokok dalam 7 hari & 21 & 70 \\
\hline & b. $2-3$ rokok / hari & 1 & 3,33 \\
\hline & c. 4-6 rokok / hari & 4 & 13,33 \\
\hline & d. $7-10$ rokok / hari & 2 & 6,67 \\
\hline & e. $11-20$ rokok / hari & 1 & 3,33 \\
\hline & f. $>20$ rokok / hari & 1 & 3,33 \\
\hline \multirow[t]{10}{*}{3.} & Merokok dalam 24 jam terakhir & & \\
\hline & a. Merokok & 8 & 26,67 \\
\hline & b. Tidak merokok & 22 & 73,33 \\
\hline & Jumlah rokok yang dihisap selama 24 jam terakhir: & & \\
\hline & a. Tidak merokok dalam 24 jam & 22 & 73,33 \\
\hline & b. $2-3$ rokok / hari & 1 & 3,33 \\
\hline & c. 4-6 rokok / hari & 4 & 13,33 \\
\hline & d. $7-10$ rokok / hari & 2 & 6,67 \\
\hline & e. $11-20$ rokok / hari & 1 & 3,33 \\
\hline & f. $>20$ rokok / hari & - & - \\
\hline \multirow[t]{5}{*}{4.} & Tipe - tipe perilaku merokok & & \\
\hline & a. Dipengaruhi perasaan positif & 6 & 20 \\
\hline & b. Dipengaruhi perasaan negatif & 10 & 33,33 \\
\hline & c. Adiktif & 18 & 60 \\
\hline & d. Sudah menjadi kebiasaan & 18 & 60 \\
\hline
\end{tabular}

Pada Tabel 3 menunjukkan bahwa responden yang merokok dalam 30 hari terakhir sebesar $33,33 \%$. Jumlah rokok yang dikonsumsi dalam 30 hari terakhir yang paling banyak adalah $>20$ batang rokok/hari yaitu sebesar $13,33 \%$ responden. Jumlah responden yang merokok dalam 7 hari terakhir sebesar $30 \%$. Jumlah rokok yang dikonsumsi dalm 7 hari terakhir yang paling banyak adalah 4-6 batang rokok/hari yaitu sebesar 13,33\% responden. Jumlah responden yang merokok dalam 24 jam terakhir sebesar $26,67 \%$. Jumlah rokok yang dikonsumsi dalam 24 jam terakhir yang paling banyak adalah 4-6 batang rokok/hari yaitu sebesar 13,33\%. Tipe-tipe perilaku merokok yang paling banyak adalah karena zat adiktif dan kebiasan yaitu sebesar $60 \%$ dan yang paling sedikit karena dipengaruhi oleh perasaan positif yaitu sebesar $20 \%$. 


\section{B. Pembahasan}

\section{Tingkat Pengetahuan Responden Tentang Rokok}

Pengetahuan adalah hasil dari tahu dan merupakan hasil penginderaan terhadap suatu objek. ${ }^{8}$ Peneliti mengkategorikan pengetahuan menjadi dua kategori yaitu pengetahuan baik, cukup baik dan kurang baik. Pada penelitian ini didapatkan hasil bahwa sebesar $46,67 \%$ responden mempunyai pengetahuan responden yang cukup baik. Peneliti mengukur pengetahuan responden tentang penyakit-penyakit yang ditimbulkan oleh rokok. Hasilnya didapat bahwa separuh responden mengetahui bahwa merokok dapat menyebabkan jantung dan penyakit hipertensi, sebesar $96,67 \%$ responden mengetahui bahwa merokok dapat menyebabkan hipotensi dan gangguan kehamilan dan sebesar $100 \%$ responden mengetahui bahwa merokok dapat menyebabkan penyakit asma dan kanker paru. Sama halnya dengan hasil penelitian lain menyebutkan bahwa separuh lebih responden $(62,7 \%)$ mengetahui bahwa merokok dalam jangka waktu lama dapat menimbulkan penyakit hipertensi. ${ }^{9}$ Merokok terbukti meningkatkan tekanan darah. Merokok sebatang setiap hari akan meningkatkan tekanan sistolik 10-25 mmHg dan menambah detak jantung 5-20 kali per menit. ${ }^{10}$

Selain itu sebagian besar responden $(89,3 \%)$ mengetahui bahwa kanker paru dapat diakibatkan oleh rokok. Aditama mengatakan bahwa faktor penyebab utama kanker paru adalah kebiasaan merokok. ${ }^{11}$ Sebagian besar responden (88\%) mengetahui bahwa merokok dapat menyebabkan penyakit jantung. Aditama juga mengatakan bahwa kebiasaan merokok berpengaruh pada jantung dan pembuluh darah melalui mekanisme aterosklerotik, gangguan metabolisme lemak, gangguan sistem homeostatik, gangguan iramajantung serta penurunan kemampuan untuk oksigenasi. ${ }^{11}$ Separuh lebih responden (66,7\%) juga mengetahui bahwa stroke adalah dampak dari merokok. Stroke sangat sering terjadi akibat hipertensi yang tak terkendali.

Seluruh responden (100\%) mengetahui bahwa nikotin adalah zat yang berbahaya bagi tubuh manusia yang terkandung dalam rokok dan sebagian besar responden (70\%) juga mengetahui bahwa karbonmonoksida adalah zat yang berbahaya bagi tubuh manusia yang terkandung dalam rokok. Hasil penelitian menyatakan dengan detail terkait pengetahuan responden tentang zat-zat kimia berbahaya dalam rokok. Dalam penelitiannya menyebutkan bahwa peneliti memberikan pertanyaan mengenai ada tidaknya zat-zat seperti nikotin, tar dan karbonmonoksida. Sebesar $48,9 \%$ responden tidak mengetahui nama-nama dari zat yang terkandung dalam rokok seperti tar dan karbonmonoksida (CO), sebagian besar responden $(85,3 \%)$ hanya mengetahui zat nikotin yang terkandung di dalam rokok. Hasil penelitian ini menungkapkan bahwa pengetahuan masyarakat masih kurang mengenai zatzat kimia dalam rokok dan efek dari zat tersebut bagi tubuh. ${ }^{9}$

Pengetahuan responden yang baik tidak berarti diikuti oleh perilaku merokok responden juga baik. Hal ini dikarekanan tingkat pengetahuan yang baik tidak selalu menyebabkan perubahan perilaku, tetapi merupakan kumpulan hal yang positif antara perubahan perilaku dan variabel-variabel lainnya yang dapat mendukung perubahan perilaku. ${ }^{12}$

Berdasarkan hasil penelitian mengatakan bahwa tingkat pengetahuan seorang perokok mengenai dampak merokok beragam disetiap negara karena dipengaruhi oleh tingkat pendidikan dan masih kurang luasnya kampanye kesehatan. ${ }^{13}$ Responden yang berpengetahuan baik namun memiliki perilaku merokok yang kurang baik dapat diakibatkan oleh perilaku merokok yang sudah menjadi kebiasaan responden. Dalam penelitian ini terdapat $60 \%$ responden yang memiliki tipe merokok karena kebiasan. Hasil 
penelitian lain menunjukkan bahwa disamping pengetahuan yang kurang, juga karena pengaruh adiksi dari nikotin yang terdapat pada rokok. ${ }^{7}$ Pada penelitian ini terdapat $60 \%$ responden yang merokok karena adiksi.

\section{Sikap Responden Terhadap Perilaku Merokok}

Sikap seseorang dapat berubah dengan diperolehnya tambahan informasi tentang suatu objek tertentu. Begitu pula halnya dengan merokok, semakin banyak manfaat yang diketahui tentang merokok semakin baik sikap yang dibentuk, begitu juga sebaliknya. ${ }^{14}$ Hasil penelitian ini menunjukkan bahwa sebesar 63,3\% responden yang memiliki sikap negatif terhadap perilaku merokok artinya responden setuju dengan penggunaan tembakau. Dengan demikian mahasiswa akan cenderung untuk berperilaku merokok. Hasil penelitian ini menunjukkan sebesar $56,67 \%$ responden beranggapan bahwa merokok sangat baik dipakai untuk menyambut tamu di acara-acara selamat di kampung. Sebesar $40 \%$ responden setuju bahwa tidak ada orang yang meninggal karena merokok, maka merokok tidak perlu dilarang. Sebesar 30\% responden setuju bahwa merokok itu merupakan hak asasi manusia sehingga merokok dapat dimana saja dan kapan saja Sedangkan responden yang memiliki sikap positif terhadap perilaku merokok dikarenakan responden mengetahui tentang bahaya rokok serta dampak yang ditimbulkan. Berdasarkan hasil penelitian ini juga didapatkan sikap positif terhadap perilaku merokok dimana sebagian besar responden menjawab setuju bahwa masyarakat juga berkewajiban memberikan informasi tentang merokok dan bahayanya kepada masyarakat lain yaitu sebesar $83,3 \%$ dan separuh lebih $(60 \%)$ responden setuju bahwa seharusnya pemerintah melarang orangorang yang merokok di tempat-tempat umum, perkantoran dan sekolah.

\section{Perilaku Merokok Responden}

Perilaku merokok terbagi menjadi perilaku merokok baik cukup baik dan kurang baik. Penelitian ini melibatkan 30 penderita hipertensi. Didapatkan hasil bahwa sebesar $66,67 \%$ perilaku merokok responden kurang baik. Peneliti mengkategorikan perilaku merokok respoden dalam 30 hari terakhir, 7 minggu terkahir, 24 jam terakhir dan berdasarkan tipe merokok. Sebesar $13,33 \%$ responden dalam 30 hari terakhir menghisap >20 batang rokok/hari. Sebesar 13,33\% responden dalam 7 hari terakhir menghisap 4-6 batang rokok/hari. Sedangkan dalam 24 jam terakhir sebesar $13,33 \%$ respoden menghisap 4-6 batang rokok/hari.

Berdasarkan jumlah rokok yang dihisap, perokok dikelompokkan menjadi perokok ringan, perokok sedang dan perokok berat. Perokok ringan adalah perokok yang merokok kurang dari 10 batang per hari. Perokok sedang adalah perokok yang menghisap rokok 10-20 batang per hari. Sedangkan perokok berat adalah perokok yang menghisap rokok lebih dari 20 batang per hari. ${ }^{15}$ Berdasarkan penggolongan tersebut dapat diketahui bahwa sebagian kecil responden (13,33\%) termasuk kedalam kelompok perokok ringan. Sama halnya dengan penelitian lain didapatkan hasil bahwa sebagian besar responden $(87,5 \%)$ termasuk kedalam kelompok perokok ringan sedangkan sebesar $12,5 \%$ responden termasuk kedalam kelompok perokok sedang. ${ }^{9}$ Berbeda dengan penelitian selanjutnya yang menunjukkan bahwa sebesar 49,8\% perokok laki-laki mengkonsumsi 11-20 batang/hari dan sebesar $5,6 \%$ mengkonsumsi $>20$ batang/hari. ${ }^{7}$ Sedangkan hasil penelitian berikutnya menyatakan bahwa sebesar $55,6 \%$ responden penderita penyakit jantung koroner merupakan perokok berat ( $\geq 20$ batang/hari). ${ }^{16}$ 
Nikotin dalam tembakau dapat menyebabkan tekanan darah meningkat setelah hisapan pertama. Selain dari lamanya merokok, risiko merokok terbesar terantung pada jumlah rokok yang dihisap perhari. Seseorang yang merokok lebih dari satu pak rokok sehari akan 2 kali lebih rentan terkena hipertensi daripada mereka yang tidak merokok. ${ }^{17}$

Berdasarkan kelompok umur, sebesar $36,67 \%$ responden adalah usia 71-80 tahun. Hasil penelitian lain menyatakan bahwa semakin meningkatnya umur responen mempunyai risiko terhadap hipertensi. Tinggina risiko pria untuk mengalami hipertensi seringkali dipicu oleh perilaku tidak sehat (merokok dan konsumsi alcohol), depresi dan rendahnya status pekerjaan, perasaan kurang nyaman terhadap pekerjaan dan pengangguran. Demikian halnya pengaruh faktor pendidikan. ${ }^{18}$ Hasil penelitian lain menunjukkan bahwa lansia yang terpapar dengan kebiasaan merokok akan meningkatkan risiko kejadian hipertensi sistolik sebesar 2,8 kali lebih besar dibandingkan dengan lansia yang tidak terpapar kebiasaan merokok. ${ }^{19}$ Hasil penelitian ini sejalan dengan penelitian berikutnya yang menyatakan bahwa lansia yang merokok mempunyai kemungkinan sebesar 1,179 kali dan 1,07 kali, lebih besar terkena hipertensi hipertensi sistolik dibandingkan dengan lansia yang tidak merokok. ${ }^{20,21}$

Berdasarkan hasil penelitian ini didapatkan bahwa tipe-tipe perilaku merokok yang paling banyak adalah karena zat adiktif dan kebiasan yaitu sebesar $60 \%$. Mereka menggunakan rokok sama sekali bukan karena untuk mengendalikan perasaan mereka, tetapi karena benar-benar sudah menjadi kebiasaan rutin. Dapat dikatakan pada orang-orang tipe ini merokok sudah merupakan suatu perilaku yang bersifat otomatis, seringkali tanpa dipikirkan dan tanpa disadari ia menghidupkan api rokoknya bila rokok yang terdahulu telah benar-benar habis. ${ }^{22}$ Sebab perilaku merokok yang lain adalah karena kecanduan, dalam penelitian ini sebesar $60 \%$ responden sudah kecanduan rokok. Hal ini akan membuat perilaku merokok menjadi lebih sulit untuk dihentikan. Responden yang sudah menjadi pecandu rokok akan menambah dosis rokok yang digunakan setiap saat setelah efek dari rokok yang dihisapnya berkurang. ${ }^{22}$ Sedangkan prosentase tipe perilaku merokok yang paling sedikit karena dipengaruhi oleh perasaan positif yaitu sebesar $20 \%$ artinya dengan merokok, responden akan merasakan penambahan rasa yang positif seperti kenikmatan setelah minum kopi atau makan akan bertambah dengan merokok. ${ }^{22}$

\section{SIMPULAN DAN SARAN}

\section{A. Simpulan}

Gambaran pengetahuan dan perilaku merokok responden sebagian besar kurang baik. Sedangkan sebagian besar responden memiliki sikap negatif yaitu sebesar $63,3 \%$.

\section{B. Saran}

Petugas kesehatan perlu memberikan layanan konseling berhenti merokok pada penderita hipertensi untuk meningkatkan kualitas hidup penderita dan membentuk satuan pengawas rokok untuk membantu mengurangi konsumsi rokok pada perokok aktif. 


\section{Daftar Pustaka}

1. Departemen Kesehatan RI, Riset Kesehatan Dasar, Kementerian Kesehatan Republik Indonesia, Jakarta, 2013.

2. Sani, A., Hipertensi dan Merokok, Jurnal Kardiologi Indonesia, vol. XVII, 1994.

3. Csanyi, Attila, Egervari, Agnes, Nagy, Z., Influende of hypertension and smoking as the single vascular risk factors on the intima-media thickness, European Journal of Epidemiology, vol. 17, pp. 855-861, 2001.

4. Departemen Kesehatan RI, Riset Kesehatan Dasar, Kementerian Kesehatan Republik Indonesia, Jakarta, 2007.

5. Supriyono, M., Faktor-Faktor Risiko Kejadian Penyakit JantungKoroner (PJK) Pada Kelompok Usia < 45 Tahun (Studi Kasus di RSUP dr. Kariadi Semarang dan RS Telogorejo Semarang, Semarang : Jurnal Epidemiologi (tidak dipublikasikan), 2008.

6. Departemen Kesehatan RI, Riset Kesehatan Dasar, Kementerian Kesehatan Republik Indonesia, Jakarta, 2010.

7. Sirait, AM, Pradono, Y., Toruan, IL., Perilaku Merokok di Indonesia, Buletin Penelitian Kesehatan, vol/no: 30(3), pp. 139-152, 2002.

8. Notoatmodjo, S., Pendidikan dan Perilaku Kesehatan, Rineka Cipta, Jakarta, 2003.

9. Ningsih, TS., Gambaran Pengetahuan dan Perilaku Merokok Pada Penderita Hipertensi di RW 09 Kelurahan Tugu Kecamatan Cimanggis Kota Depok, Skripsi, Fakultas IImu Keperawatan Program Sarjana Reguler Universitas Indonesia, Depok, 2012.

10. Sitepoe, M., Kekhususan rokok di Indonesia, Grasindo, Jakarta, 2000.

11. Aditama, TY., Rokok dan Kesehatan, Penerbit Universitas Indonesia (UI-Press), Jakarta, 1997.

12. Green, LW., Kreuter, MW., Health Promoting Planning : An Educational And Environment, Mayfield Publishing, 1991.

13. Crofton, J., Simpson, D., Tembakau: Ancaman Global, PT. Elex Media Computindo, Jakarta, 2009.

14. Sarwono, Sosialisasi Kesehatan, Gadjah Mada University Press, Yogyakarta, 2004.

15. Bustan, MN., Epidemiologi Penyakit Tidak Menular, Rineka Cipta, Jakarta, 2007.

16. Umar, F, Citrakesumasari, Jafar, N., Perilaku Merokok dan Lingkungan Pemukiman Pasien Rawat Jalan Penyakit Jantung Koroner di Makasar, Media Gizi Masyarakat Indonesia, $\mathrm{vol} / \mathrm{no}: 1(1)$, pp. 21-28, 2011.

17 Manik, M. E., Faktor-Faktor yang Berhubungan dengan Hipertensi pada Lansia Wilayah Kerja Puskesmas Parsoburan Kecamatan Siantar Marihat Pematangsiantar Tahun 2011, Skripsi, Universitas Sumatera Utara, 2011.

18. Rahajeng, E., Tuminah, S, Prevalensi Hipertensi dan Determinannya di Indonesia, Majalah Kedokteran Indonesia, vol/no: 59(12), pp. 581-587, 2009.

19. Lewa, A. F, Pramantara, D. P., Rahayujati, B, Faktor-Faktor Risiko Hipertensi Sistolik Terisolasi pada Lanjut Usia, Berita Kedokteran Masyarakat, vol/no: 26(4), pp. 171-178, 2010.

20. Xu C, et al, Prevalence of risk factors for isolated systolic hypertension in the rural adult population of Lianiong Province, China, The Journal of International Medical Research, vol. 36, pp. 353-5, 2008.

21. Franklin, S. S, et al, Predictors of new onset diastolic and systolic hypertension: The Framingham Heart Study, Circulation Journal of American Association, vol .3, pp. 1121-7, 2005.

22. Nurhayati, I., Bahaya Rokok Bagi Tubuh (Telaah Pustaka), Jurnal Keperawatan eM-U, Vol/No: IV(12), 2012. ISSN : 2085.2754.17. Nurhayati, I., Bahaya Rokok Bagi Tubuh (Telaah Pustaka), Jurnal Keperawatan eM-U, vol/no: IV(12), 2012. ISSN : 2085.2754. 